\title{
Winter feeding - changing labour requirements and productivity
}

\author{
D.R. STEVENS ${ }^{1}$, M.J. CASEY ${ }^{2}$, J.S. SCANDRETT ${ }^{3}$, and G.S. BAXTER ${ }^{3}$ \\ ${ }^{1}$ AgResearch Invermay, Private Bag 50034, Mosgiel \\ ${ }^{2} P G G$ Wrightson Ltd, Dunedin \\ ${ }^{3}$ Scandrett Rural Ltd, Invercargill \\ david.stevens@agresearch.co.nz
}

\begin{abstract}
Current winter feeding practice using a daily grazing duration to ration feed is based on the sheep industry of the 1960 s to the 1980 s when per head performance was much lower than today. This study investigated the impact of changing from a 1-day grazing duration to a 4-day grazing duration during winter on subsequent productivity. Ewe condition score and liveweight, tailing percentages, and tailing and weaning weights of lambs, as well as the incidence of vaginal prolapse in ewes at lambing were recorded over several years on a total of seven farms. Spring pasture growth and botanical composition was measured on one farm. Results suggest 4-day shifting had little impact on vaginal prolapse but did result in more settled sheep, easier winter shifting regime, and less pasture damage, leading to improved pasture production in early spring $(\mathrm{P}<0.01)$. Changing to a 4-day shifting regimen also decreased labour requirements.
\end{abstract}

Keywords: body condition score, ewe, grazing duration, lamb growth, liveweight, spring pasture production, stolons, tillers, winter.

\section{Introduction}

Improving the understanding of the relationship between winter ewe nutrition, feed management, productivity and profitability is critical to the sheep industry. Many of our wintering practices are based on research from the 1960s to 1980s when our sheep flock of nearly 70 million ewes produced as much lamb meat as we now do from 40 million sheep (Cocks \& Brown 2005). New Zealand sheep research during the 1960 s to 1980 s reported ewes of 45 to $55 \mathrm{~kg}$ (e.g. Smeaton \& Rattray 1984) while recent research (e.g. Kenyon et al. 2011) reports ewes of 60 to $70 \mathrm{~kg}$. This potential change in live weight increases winter feed requirements from the earlier recommendations of feed allowances during mid-winter. To get a ewe to produce twins or triplets with higher birth weights (Thompson et al. 2004) and with weaning weights that may be 3 to 10 $\mathrm{kg}$ heavier (Smeaton \& Rattray 1984; cf. Kenyon et al. 2011; Thompson et al. 2004) than in the 1980s requires ensuring that feed requirements in winter are met. This provides the opportunity to change the way we manage our ewes in winter, as we are no longer aiming to offer below maintenance levels of feed, and so ewes should not be hungry.

Anecdotal evidence from farmers has suggested that the traditional wintering programme of daily grazing durations can be altered to durations of between 3 and 5 days with no detrimental impact on pastures, while potentially decreasing the incidence of vaginal prolapse and reducing winter workload. An initial investigation on the South Otago monitor farm (2005-2007) found that reducing the fluctuations in ewe live weight during winter significantly reduced the incidence of vaginal prolapse around lambing from between 5 and $7 \%$ to between 1 and 3\% (Stevens \& Casey 2008). Changing the grazing regimen during early pregnancy (day 40 to day 90 ) further reduced vaginal prolapse from $3 \%$ to $0.7 \%$ in one year and 2.6 to $1.5 \%$ in a second year for 2-day compared with the 4-day grazing durations respectively.

This study, over two years, investigated the opportunity to instigate a 4-day grazing duration regimen in the highly stocked and heavy soils of Southland. The aim was to provide farmers with robust management guidelines to implement a less labour intensive regimen of feeding while helping to improve sheep performance.

\section{Materials and Methods \\ On-farm comparisons of a 1-day with a 4-day grazing duration regimen}

Comparisons were done on three farms in each of 2 years, using a separate set of farms each year. The farms, selected for a previous history of vaginal prolapse (occasionally greater than $5 \%$ of ewes affected), were located throughout Southland, specifically at Waimahaka, Tokanui, Pahia, South Hillend, Te Tipua and Pukerau, and ranged from flat to rolling to moderately steep topography on predominantly Brown soil types.

On each farm in mid-May the flock of mixed age ewes was randomly split into two mobs to be allocated to either a 1-day or 4-day grazing duration regimen for the following 45-50 days to pregnancy scanning. Mob size ranged from 736 to 1170 ewes. A total of 11,570 ewes were monitored during the comparisons. Pregnancy 


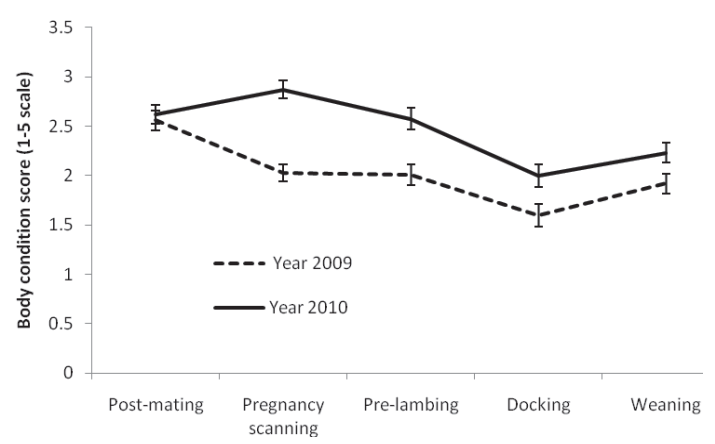

Figure 1 Body condition scores in two years in commercial flocks of twin-bearing ewes during pregnancy and lactation.

scanning estimated that lambing potential was between 165 and 185 lambs per 100 ewes mated. Whole farm feed budgets were done at this time with ewes being allocated a maintenance diet based on liveweight. Feed allocations were calculated every two weeks, based on a pasture walk and measured pasture yield using a plate meter (Farmworks F400). Assessments of potential pasture utilisation were made, based on the amount of dead material in the pasture and the total amount of pasture on offer, and feed allocation on a dry matter basis adjusted accordingly. At pregnancy scanning, farmers followed their own feeding practices until trial completion at weaning. Those practices may have included the use of crops (three farms used swedes, 4 to 6 weeks), or remaining on pasture with supplements of hay or baleage (three farms). The two flocks were able to be recombined at this time if required for management purposes. All flocks were set stocked for lambing, at between 1 and 3 weeks prior to planned start of lambing, until weaning at approximately day 85 of lactation.

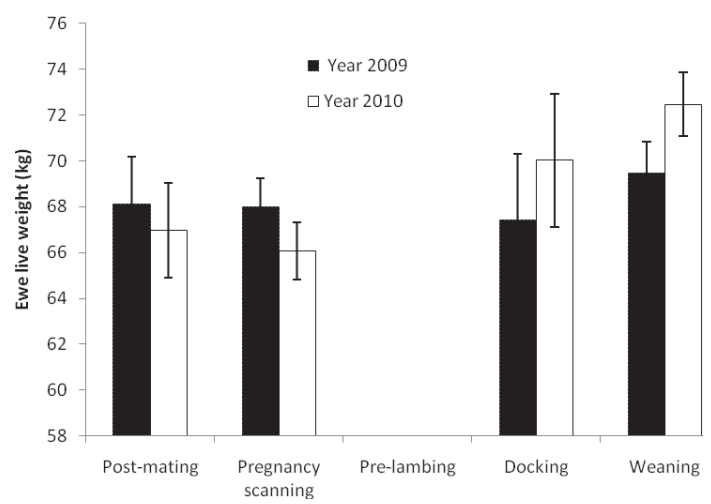

Figure 2 Live weight changes of twin-bearing ewes in commercial flocks in two years during pregnancy and lactation

Approximately 160 ewes in each grazing group on each farm were tagged at the beginning of the demonstration immediately post-tupping. Following scanning, a cohort of between 100 and 140 twinbearing ewes were monitored for live weight and body condition score (by the method of Russel et al. 1969) during pregnancy and lactation. Live weight was taken post-tupping, at scanning, at tailing and weaning, and an extra body condition score measurement was done at approximately 4 weeks prior to lambing (at vaccination). The incidence of vaginal prolapse was recorded as it occurred. Live weight of the twinborn lambs was measured in a sample of lambs at birth $(\mathrm{n}=20$ per treatment), day 20 (tailing, $\mathrm{n}=100$ ) and day 80 (weaning, $n=100$ ) from the average birth date, estimated to be 10 days after the planned start of lambing.

Pasture quality of the pasture offered was measured by near-infrared spectroscopy (Corson et al. 1999) during May and June each year.

Table 1 Average body condition score and liveweight of ewes on 1-day or 4 day grazing durations throughout mid-pregnancy in two years, and the live weight of their twin-born lambs at birth, 20 days (tailing) and 80 days (weaning), and growth rate of the lambs from tailing until weaning.

\begin{tabular}{|c|c|c|c|c|c|c|c|c|c|}
\hline & & \multicolumn{4}{|c|}{ Grazing duration } & \multicolumn{4}{|c|}{ Year } \\
\hline & & 1 Day & 4 Day & Signif. & Isd & 2009 & 2010 & Signif. & Isd \\
\hline \multirow[t]{2}{*}{ Ewes } & Body Condition Score ${ }^{1}$ & 2.24 & 2.24 & ns & 0.09 & 2.02 & 2.46 & 0.001 & 0.09 \\
\hline & Average live weight $(\mathrm{kg})$ & 68.7 & 68.4 & ns & 2.77 & 68.2 & 68.9 & ns & 2.77 \\
\hline \multirow[t]{4}{*}{ Lambs } & Birth weight $(\mathrm{kg})$ & 5.4 & 5.1 & ns & 0.4 & 5.2 & 5.3 & ns & 0.35 \\
\hline & 20 day weight $(\mathrm{kg})$ & 11.8 & 11.9 & ns & 0.53 & 11.9 & 11.8 & ns & 0.53 \\
\hline & 80 day weight $(\mathrm{kg})$ & 27.6 & 27.4 & ns & 0.63 & 26.7 & 28.3 & 0.017 & 0.63 \\
\hline & Gain day 20 to 80 (g/d) & 259 & 254 & ns & 17.9 & 242 & 271 & 0.003 & 17.9 \\
\hline
\end{tabular}

\footnotetext{
${ }^{1}$ Body condition score ranked on a 1 (low) to 5 scale as per Russel et al. (1969)
} 
Table 2 The response of pasture growth rates ( $\mathrm{kg} \mathrm{DM} / \mathrm{ha} /$ day) to grazing durations of 1 or 4 days after a single grazing event in June 2010 when soils were either saturated or at field capacity.

\begin{tabular}{lccccccc}
\hline & \multicolumn{3}{c}{ Grazing duration } & \multicolumn{5}{c}{ Soil conditions } \\
\cline { 2 - 7 } & 1 Day & 4 Day & Signif. & $\begin{array}{c}\text { Field } \\
\text { capacity }\end{array}$ & Saturated & Signif. & Isd \\
\hline August & 7.6 & 13.6 & $<0.001$ & 12.4 & 8.8 & 0.001 & 2.03 \\
September & 23.3 & 28.5 & 0.015 & 29.1 & 22.8 & 0.004 & 4.11 \\
October & 52.3 & 54.7 & $\mathrm{~ns}$ & 57.8 & 49.2 & 0.05 & 8.55 \\
November & 103.7 & 133.9 & $<0.001$ & 121.6 & 116.1 & $\mathrm{~ns}$ & 15.06 \\
December & 63.7 & 84.7 & $<0.001$ & 74.4 & 73.9 & $\mathrm{~ns}$ & 10.9 \\
\hline Spring total (kg DM/ha) & 6940 & 8730 & $<0.001$ & 8260 & 7400 & 0.02 & 711 \\
\hline
\end{tabular}

The data was analysed as mean responses from each farm using the general linear model (GenStat 2008) with shifting frequency and year being the fixed effects while the farm was the random effect.

\section{Effects of 1-day and 4-day shifting on pasture growth and composition}

Two pastures on a single farm, both of a Woodlands Brown soil type ( $\mathrm{pH}$ 6.0; Olsen P $20 \mathrm{ug} / \mathrm{ml}$; $\mathrm{SO}_{4} \mathrm{~S} 13$ $\mathrm{ppm}$ ), were chosen as representative of typical winter grazing damage in Southland. Each pasture had been grazed by approximately 1170 ewes at a stocking density of 1706 and 365 ewes/ha/day (1-day and 4-day grazing durations respectively). Both mobs were offered $1.22 \mathrm{~kg} \mathrm{DM} /$ ewe/day above a residual of 500 $\mathrm{kg} \mathrm{DM} / \mathrm{ha}$.

Experimental design on these pastures was a $2 \times$ 2 factorial in 2 replicates. The factors were 1-day and 4-day gazing durations, and field capacity and saturated grazing conditions. The replicates included two grazing periods before and two after the rainfall event. Pastures were paired for time since renovation, botanical composition and slope. Four pasture cages were set up in each replicate and monitored for pasture growth monthly from 23 June 2010 until 22 December 2010, as well as grass tiller and clover stolon numbers in August and December (Mitchell \& Glenday 1958), and botanical composition by herbage dissection in November and December. Cages were shifted monthly onto sites pre-trimmed to a height of $1 \mathrm{~cm}$ during the experimental duration and pasture cut back to this height to measure growth. Data were analysed using ANOVA (GenStat 2008).

\section{Results}

The overall incidence of vaginal prolapse was not significantly different between the 1-day or 4-day grazing duration, being 2.65 and $2.12 \%$ respectively $(\mathrm{P}>0.05)$, from a total of 11,570 ewes equally represented in each shifting regimen. The numbers of vaginal prolapse cases reported in each year were also not significantly different, being 2.49 and $2.28 \%$ from 4756 and 6754 ewes in 2009 and 2010 respectively.

There were no significant differences in ewe liveweight or condition score between the 1-day and 4-day grazing duration regimens, therefore average figures are presented in Table 1. There was a significant interaction between year and time of measurement in condition score (Figure 1) with ewes losing a significant amount of condition from post-mating to scanning in 2009 , compared with a small gain in 2010. Condition score remained higher in the ewes in 2010 for the remainder of the demonstration. Ewe live weight (Table 1) was also different between years, with ewes in 2010 being lighter than those in 2009 at pre-mating and scanning, but heavier at tailing and weaning (Figure 2).

Shifting regimen did not significantly affect lamb live weight at birth, day 20 (tailing) or day 80 (weaning) (Table 1), though weaning weight was significantly higher in 2010 than in 2009, as was live weight gain from tailing to weaning.

\section{Effects on pasture growth and composition}

One of the aspects of 4-day shifting for wintering is the perceived reduction in pasture damage compared to 1-day shifting. Rainfall around 22 June 2010 created conditions that caused stock to damage pasture, with $36 \mathrm{~mm}$ falling in 3 days, creating a surplus over field capacity of $34.5 \mathrm{~mm}$ (Gore AWS, NIWA). Prior to that time areas of both 1- and 4-day grazing durations showed no visual soil damage, though soils were near field capacity.

Pasture growth from pastures under the 1-day shifting regimen was lower than that from the 4-day regimen during the early spring (July-September 2010, Table 2) and again in November and December. Final pasture production was significantly higher on the pastures that received the 4-day grazing regimen during winter. Grazing during saturated soil conditions significantly reduced the pasture growth rate during the early spring (July-September 2010, Table 2). 
Table 3 Impacts of grazing duration and soil conditions during grazing on the grass tiller numbers and white clover stolon length and growing point numbers.

\begin{tabular}{|c|c|c|c|c|c|c|c|c|}
\hline & \multirow{2}{*}{$\begin{array}{l}\text { Grazing duration } \\
\text { Soil conditions }\end{array}$} & \multicolumn{2}{|c|}{1 Day } & \multicolumn{2}{|c|}{4 Day } & \multicolumn{3}{|c|}{ Statistics } \\
\hline & & $\begin{array}{c}\text { Field } \\
\text { capacity }\end{array}$ & Saturated & $\begin{array}{c}\text { Field } \\
\text { capacity }\end{array}$ & Saturated & Type & $P$ & Isd \\
\hline \multicolumn{9}{|l|}{ August } \\
\hline \multirow[t]{4}{*}{ Tiller number $/ \mathrm{m}^{2}$} & Ryegrass & $5250 a^{1}$ & $2600 \mathrm{c}$ & $4790 a b$ & $4130 \mathrm{~b}$ & Interaction & 0.021 & 983 \\
\hline & Poa & $3870 \mathrm{~b}$ & $3820 \mathrm{~b}$ & $10500 \mathrm{a}$ & $7330 \mathrm{a}$ & Grazing & 0.026 & 3930 \\
\hline & Others & 410 & 250 & 610 & 710 & ns & ns & 2030 \\
\hline & Total & $9580 \mathrm{~b}$ & $6670 \mathrm{~b}$ & $15890 \mathrm{a}$ & $12680 \mathrm{a}$ & Grazing & 0.023 & 4523 \\
\hline \multirow[t]{3}{*}{ White clover } & Length $\left(\mathrm{cm} / \mathrm{m}^{2}\right)$ & 4790 & 4020 & 10750 & 5190 & ns & & 4730 \\
\hline & Growing points $/ \mathrm{m}^{2}$ & 12370 & 9010 & 18030 & 10640 & Grazing/soil & $0.02 / 0.007$ & 2577 \\
\hline & Growing points/cm & 2.57 & 2.25 & 1.75 & 2.04 & ns & ns & 0.76 \\
\hline \multicolumn{9}{|l|}{ December } \\
\hline \multirow[t]{4}{*}{ Tiller number $/ \mathrm{m}^{2}$} & Ryegrass & 5810 & 5760 & 4580 & 2903 & ns & & 4232 \\
\hline & Poa & 2500 & 3260 & 4280 & 3510 & ns & & 3570 \\
\hline & Others & 810 & 360 & 4330 & 5550 & Shift freq & 0.033 & 3720 \\
\hline & Total & 9120 & 9370 & 13240 & 11920 & ns & & 4570 \\
\hline \multirow[t]{3}{*}{ White clover } & Length (cm) & 5190 & 3360 & 8150 & 3920 & ns (Soil) & 0.075 & 3626 \\
\hline & Growing points $/ \mathrm{m}^{2}$ & 14310 & 7540 & 26320 & 9070 & ns (Soil) & 0.052 & 9137 \\
\hline & Growing points/cm & 2.74 & 2.29 & 2.50 & 2.31 & ns & ns & 0.55 \\
\hline
\end{tabular}

In August 2010 grass tiller numbers, clover stolon growing points and stolon length were significantly lower on pastures that were grazed during saturated soil conditions than near field capacity soils (Table 3). Ryegrass tillers were affected along with other grasses (mainly Poa аппиа and Agrostis stolonifera). Tiller numbers and stolon growing points and length in August were also affected by grazing duration in winter (Table 3).

There were significantly more grasses other than ryegrass in the 4-day grazing duration pastures, but no other significant differences between the grazing regimens or soil moisture conditions during grazing were found in the tiller numbers. Stolon growing points and length showed a trend towards greater clover stolon length and growing points in the pastures that had been grazed at or below field capacity when measured in late December (Table 3).

\section{Discussion}

The use of 1-day or 4-day grazing regimens in winter did not provide a significant reduction in vaginal prolapse cases as found in the previous study (Stevens \& Casey 2008). Similar numbers of vaginal prolapse cases between the years suggests that the causative agent was present and is yet to be defined.
The live weight and condition score profiles were similar on each farm within years, suggesting that the ewes were able to achieve the same intake on both grazing regimens when accurate feed budgeting allocated the appropriate feed requirements. Initial differences in live weight were most likely due to different mature ewe weights on the different farms, as body condition score at post-tupping was similar in both years. The significant divergence in condition score between the years may have been attributable to lower than anticipated utilisation of pastures during very wet soil conditions during late May and early June 2009. This difference was then maintained through until weaning, indicating the importance of maintaining condition score during winter, as the loss in condition during the early lactation period (to tailing) was present in each year. This was further highlighted by the increase in lamb weaning weight in 2010, even though conditions during spring 2010 had snow on the ground for 6 to 10 days during September. This study highlights the importance of accurate feed budgeting in achieving feeding targets for ewes in winter, and reinforces the need to maintain good body condition score on ewes to maximise lamb performance during spring (Kenyon et al. 2011). 
The impacts of treading damage to pastures during winter are well known (Edmond 1964). However, with daily grazing durations treading damage has been accepted, and often farmers shift mobs even more frequently (twice daily) during periods of significant soil saturation. The increase in pasture production using the 4-day grazing duration regimen appears related to lower tiller damage, in conditions of both saturated and nonsaturated soils. The stocking density was significantly lower in the 4-day grazing duration treatment, but may have been aided by lower stock movement, as farmers have noted that stock are more settled on the 4-day shifting regimen. This observation and its impact on pasture damage needs to be confirmed with more study. Longer term implications of the significant presence of other weed grasses needs to be investigated.

Previous research extending grazing duration in winter has provided mixed results. Hayman \& Moss (1979) found little difference in spring production in pastures that had been grazed for 2, 4 or 7 days during winter $(1500,750$ and 430 ewes/ha), but that was under very intense grazing pressure that reduced the pasture residual after grazing to approximately $200-400 \mathrm{~kg} \mathrm{DM} /$ ha. Sheath (1982) found that extending grazing duration from 3 days to 15 days increased ewe intake and pasture utilisation, as well as achieving a more uniform postgrazing residual.

Farmer comment from the project indicated that a 4-day grazing duration was definitely preferred as not only did it reduce labour requirement, it also reduced wear on machinery such as four-wheel motor bikes, and gave the farmers options to increase mob numbers and achieve more directed feeding programmes based on features such as body condition score.

\section{ACKNOWLEDGEMENTS}

The authors thank the MAF Sustainable Farming Fund, Beef + Lamb New Zealand, PGG Wrightson and Scandrett Rural Ltd for funding, the farmers for many hours of work and data recording, and Bryan Thompson and Karren O'Neill for technical assistance.

\section{REFERENCES}

Cocks, J.; Brown, C. 2005. Long-term analysis of price, productivity, and profitability trends in New Zealand agriculture. Proceedings of the New Zealand Grassland Association 67: 9-17.
Corson, D.C.; Waghorn, G.C.; Ulyatt, M.J.; Lee, J. 1999. NIRS: Forage analysis and livestock feeding. Proceedings of the New Zealand Grassland Association 61: 127-132.

Edmund, D.B. 1964. Some effects of sheep treading on the growth of 10 pasture species. New Zealand Journal of Agricultural Research 7: 1-16.

GenStat 2008. Release 11.1 ( PC/Windows) Copyright 2008, VSN International Ltd.

Hayman, J.M.; Moss, R.A. 1979. Grazing irrigated pasture with sheep: effect of winter management on pasture regrowth. New Zealand Journal of Experimental Agriculture 7: 277-280.

Kenyon, P.R.; Morris, S.T.; Stafford, K.J.; West, D.M. 2011. Effect of ewe body condition and nutrition in late pregnancy on the performance of triplet-bearing ewes and their progeny. Animal Production Science 51: 557-564.

Mitchell, K.J.; Glenday. A.C. 1958. The tiller population of pastures. New Zealand Journal of Agricultural Research 3: 305-313.

Russel, A.J.F.; Doney, J.M.; Gunn, R.G. 1969. Subjective assessment of fat in live sheep. Journal of Agricultural Science, Cambridge 72: 451-454.

Sheath, G.W. 1982. Some effects of grazing duration and subdivision on pasture utilization in hill country. Proceedings of the New Zealand Grassland Association 43: 215-222.

Smeaton, D.C.; Rattray P.V. 1984. Winter-spring nutrition and management effects on ewe and lamb performance. Proceedings of the New Zealand Grassland Association 45: 190-198

Stevens, D.R.; Casey M.J. 2008. Reducing bearings on high performance sheep farms. Final Report on project 07FT190 to Meat \& Wool NZ.

Thompson, B.C.; Muir, P.D.; Smith, N.B. 2004. Litter size, lamb survival, birth and twelve week weight in lambs born to cross-bred ewes. Proceedings of the New Zealand Grassland Association 66: 233-237. 
